International Journal of Social Sciences and Humanities
Available online at http://sciencescholar.us/journal/index.php/ijssh
Vol. 3 No. 2, August 2019, pages: $224 \sim 237$
e-ISSN: 2550-7001, p-ISSN: 2550-701X
https://doi.org/10.29332/ijssh.v3n2.318

\title{
Gender and Work-Life Balance: A Phenomenological Study on Balinese Female Auditor
}

\author{
CrossMark \\ Ni Ketut Dian Juliantini a , I Putu Sudana ${ }^{b}$, Herkulanus Bambang Suprasto c, I Gusti Ayu Made Asri \\ Dwija Putri ${ }^{\mathrm{d}}$
}

Article history: Received 18 December 2018, Accepted: 30 April 2019, Published: 19 August 2019

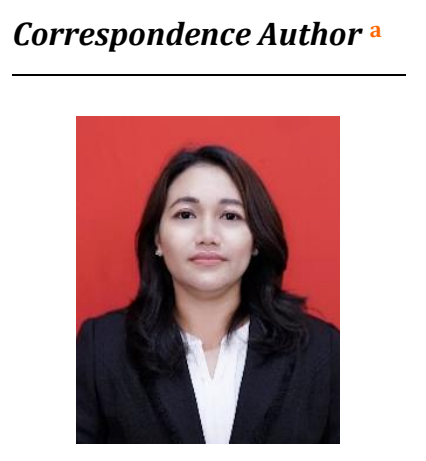

Keywords

auditor;

female;

gender;

male;

work-life;

\section{Abstract}

The auditor is one promising profession to current and the future. The number of women auditors currently is higher than in men. However, the number of female auditors currently has positively increased. Balinese female auditor's research used an interpretive phenomenology analysis approach in exploring understanding. The subjects of this study involved three Balinese female auditors. Data mining was carried out by conducting in-depth interviewees to gain an understanding of the interviewer's role as auditors of Balinese women in a dual role. The excavation results show the auditors have the concept of work-life balance always happy in life and always grateful. The highest motivation and support of interviewees is their family. Work-life balance is a challenge in life, namely, career, family, and social aspects in the customs form. The alternative work arrangements development is felt to be a solution to reduce work-life conflict and female auditor fatigue.

e-ISSN: 2550-7001, p-ISSN: 2550-701X ๑ Copyright 2019. The Author. SS Journals Published by Universidad Técnica de Manabí. This is an open-access article under the CC BY-SA 4.0 license (https://creativecommons.org/licenses/by-sa/4.0/) All rights reserved.

\section{Contents}

Abstract

1. Introduction .

2. Materials and Methods.

3. Results and Discussions

3.1 Informant.

3.2 Representing Work-life Balance 289

3.3 Finding Motivation Trigger 230

3.4 Challenges in Achieving Work-life Balance 230

a Udayana University, Denpasar, Indonesia

b Udayana University, Denpasar, Indonesia

c Udayana University, Denpasar, Indonesia

d Udayana University, Denpasar, Indonesia 
4. Conclusion

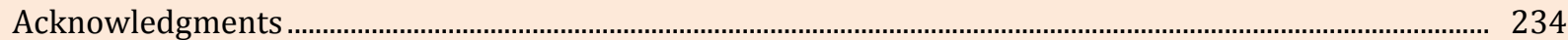

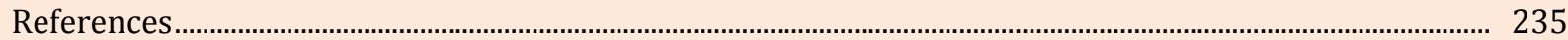

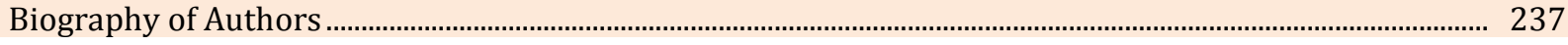

\section{Introduction}

Increasing women's participation in the auditor profession has been changed gender structure in the employee market in Indonesia. The growth of female auditors presents challenges and paves the way for research to explore hidden assumptions about motivation, life journey, and social relationships of a female auditor. The government policies set is regarded as gender mainstreaming has provided many insights into the men and women roles. However, it still reveals gaps in knowledge about how women develop their professional auditor's careers during their life journey.

Miss-understanding often occur is related to gender. Gender is actually more related to men and women roles in life. The role in question is not the biological role of men and women. However, gender emphasizes how a person takes a role in the social order. Indonesia has included PUG in national activities more than 17 years ago. It is even ranked 84 out of 144 countries ranked (Hausmann et al., 2017). The gender equality development in the world based on The Global Gender Gap Report 2017 shows a negative trend. Even, it was regarded as a small difference. The finding shows inequality. It was occurred throughout 2017 actually increased when viewed throughout the world.

Balinese people are Hindu about $83.46 \%$. Balinese people daily life are still thick in their culture. In accordance with the patriarchal concept, it is still adhered by Indonesia people. They also have a similar concept. The Balinese who in their daily life are dominantly influenced by Hinduism values. It is familiar with the concepts of Purusa and Pradana. The concept actually symbolizes the body and soul. Wherein, the soul (spirit/spiritual) and body (material/thing) is a universe form. Respecting Ardhanariswari concept shows the women have the same position as men (Suarmika \& Utama, 2018; Aditya \& Kusuma, 2019).

Balinese women are sexually dominated by Balinese men (Darmayanti, 2014). The most visible thing is Balinese women implementation in determining their choices and conveying their voices. Women's decision to work is strongly influenced by the number of dependents and customary activities (Mayaswari \& Yasa, 2019). However, the challenge of being harmonious in life is still being fought for.

The auditor profession is better known as a male profession. This condition provides an understanding of the men dominance in the auditor profession. The researchers cited data from the 2018 public accountants and public accountants directory compiled by the Indonesian Institute of Certified Public Accountants. The directory recorded the number of Certified Public Accountant (CPA) holders who have become members of the Indonesian Public Accountants Association (IAPI) is 2,571 people. The average proportion for CPA over five years is in the range of 3 to 1 . It provided evidence that the accounting profession is indeed dominated by men. However, the development of the female CPAs number from 2013 to 2017 can provide a positive signal for the women. CPA increase from year to year has increased. In 2017, the female CPA addition is to reach $33 \%$. The increase from the previous five years in 2013 is only reached $15 \%$.

Work-life balance is important for every individual to have a balanced life quality. It is between work relationships and personal life. Work-life balance requires individuals to be able to manage and divide time appropriately. If the work-life balance is not fulfilled. It results in low job satisfaction, work-life conflict, burnout for workers, and low happiness. It is related to work-life balance. Dewi \& Holiawati (2016), stated work-life balance has no influence on audit quality and gender influences the work-life balance and locus of control variables on audit quality. Accountants in the future consider the work-life balance problem as very important in making career decisions. The female accountants give a higher valuation in assessing the importance of life balance (Smith et al., 2010). The research raised the gender phenomena and work-life balance has been a lot conducted. However, it was very difficult to find research that raised gender phenomena and work-life balance from the phenomenon perspective itself.

The research on gender issues in accounting has provided many insights into the relationship between gender and auditor in terms of quality. Potential misstatements in audited financial statements are mostly

Juliantini, N. K. D., Sudana, I. P., Suprasto, H. B., \& Putri, I. G. A. M. A. D. (2019). Gender and work-life balance: A phenomenological study on Balinese female auditor. International Journal of Social Sciences and Humanities, 3(2), 224-237. https://doi.org/10.29332/ijssh.v3n2.318 
found by female auditors (Breesch \& Branson, 2009). The female auditors also avoid the risk of more than male auditors (Hardies et al., 2009). The differences in audit quality between men and women occur due to problem-solving abilities, risk avoidance, and independence (Hardies et al., 2009). The female audit existence engagement partner implies that the female auditors may have an inhibiting effect on earnings management (Ittonen \& Peni, 2012; Niskanen et al., 2011; Dewi \& Dewi, 2018).

The female auditor profession has developed significantly. It is more mature in developed countries, knowledge about female auditors phenomenon generally is still low. The female auditor's studies on developing countries are still scarce, especially, the essence context the experienced by a female auditor with multiple roles. It is felt to be very under-researched in this field.

The current study focuses on women who work as government auditors. They are married. They have children and in their social life are framed by the uniqueness of Balinese culture. The researcher felt it was very important to see how Balinese female auditors interpreted her dual role, and under what conditions the meaning occurred. The problem can be formulated. (1) How female auditors interpret their dual role as social beings and auditors? (2) In the environment and situation, how is the meaning obtained?

The qualitative research paradigm is rooted in American cultural anthropology and sociology. It aimed to understand certain social situations, events, roles, groups, or interactions. The researchers gradually understand a social phenomenon by emphasizing, comparing, replicating catalogs and classifying research objects. The qualitative researchers primarily focus on meaning. It is more preoccupied with the experience quality rather than cause-and-effect relationships.

Qualitative research is begun from the assumption and use of interpretive/theoretical frameworks. It is to inform the research problems discussed on the meaning of individuals or groups related to social or human problems (Creswell, 2007). In order to study this problem, the qualitative researcher used a qualitative approach that emerges for investigation, data collection in natural settings. They are sensitive to the people and places studied. Data analysis is inductive and deductive in nature and establishes patterns or themes. The final written report or presentation includes participant's voice, researcher reflexivity, complex description, and problem interpretation, and its contribution to the literature or calls for changing.

The following outlines are some unique characteristics inherent in qualitative research design. It has occurred in the natural environment. Human behavior and events occur based on assumptions that are very different. Regarding qualitative designs and qualitative research does not require a theory or hypothesis. The researcher is the main instrument in data collection. Data arises from qualitative research are descriptive, data sorted into words and not numbers; the focus of qualitative research is on participants' perceptions and experiences, and the way they understand their lives. Therefore, the efforts to understand an experience sometimes through multiple realities; focusing on the occurred processes. Thus, the researchers are very interested in understanding how things happen; use idiographic interpretation. Wherein, the attention is paid to specific matters. Data are interpreted in detail and not generalized. The interpretation is negotiated with the location data source. It relies on the use of intuitive knowledge. The data produced cannot be measured. The objectivity and honesty of researchers are very important in qualitative research.

Cresswell (2003), recommended five strategies for conducting qualitative research, namely narrative, phenomenology, ethnography, case study, and grounded theory. There are four procedures in qualitative research collection namely observation, interviews, document collection, and collection of audio and visual material. The research observation method is making field notes about the behavior and individual activities at the studied location. The notes are made in an unstructured manner. The researchers conducted interview method face-to-face interviews with participants, interviews with participants by telephone, or were involved in group interviews with six to eight people interviewed in each group. The interview involves unstructured and generally open questions. They are few in number and are intended to gain views and participant opinions. During the research process, qualitative research can collect documents in the form of public documents, unlike newspapers, minutes of meetings, official reports, or personal documents. Unlike the personal journals and diaries, letters, and e-mails. Audio and visual material collected can be in the form of photos, art objects, video cassettes, or any form of sound.

Phenomenological studies illustrate general meaning for some individuals from their concept or phenomenon experiences. Phenomenologists focused on describing the similarities for all informants. If they experience phenomena, for example, sadness universally experienced. The phenomenology basic aim is to reduce individual experience with phenomena to universal essence description. For this purpose, qualitative 
researchers identify a phenomenon, an "object" of human experience. The investigator, then, collected data from people who have experienced the phenomenon and develops a combined description of the experience essence for all individuals. This description consists of "what" they experience and "how" they experience it.

Interpretative phenomenological analysis (IPA) is an introduction. IPA deals with a detailed examination of personal life experiences by recognizing the phenomenological commitment to examine a topic, as far as possible, in its own way. For IPA, this inevitably involves interpretive processes on researchers and informants part. IPA is explicitly committed to understanding, interesting phenomena from a first-person perspective and its belief in subjective knowledge value for psychological understanding. The IPA primary aim is to investigate how individuals understand their experiences. It can be assumed that humans are "selfinterpreting beings". It means that they are actively involved in interpreting events, things, and people in their lives. In order to examine this process, IPA refers to the basic principles of phenomenology, hermeneutics, and idiography.

IPA was first articulated in Britain (Smith, 1990). It was originally taken as an approach to psychology experiences in health and psychology. IPA is committed to clarifying and explaining a phenomenon (it is an event, process or relationship) by focusing on the process of explaining experienced to people who are in a similar socio-historical environment. It aims to understand the texture and quality of experience. Due to it is lived by experienced subjects. The primary interest is on the person's experiences related to the phenomena and feelings. They make from their experiences rather than focusing on the structure of the phenomenon itself.

Smith \& Osborn (2008), stated IPA has three main features, namely experience, idiography, and interpretation. The experience is intended subject to be understood in the context of a concrete and meaningful human world. It attends all aspects of life experience, ranging from desires, expectation, feelings, motivations, individual belief systems to how life experiences are present in one's behavior and actions. Idiography deals with how to understand the concrete, special, and unique while maintaining personal integrity. Idiography researchers tend to get closer to general aspects. This is important in connecting the unique lives of individuals with the same humanity. IPA studies are more generally using small samples. Therefore, each individual can be attended ideographically before trying a comparative analysis of material from participants.

IPA is an explicit interpretive effort on hermeneutics basis. Interpretation is to describe the hidden meaning in the visible meaning. Analytical processes are often described in terms of multiple hermeneutic processes or multiple interpretations. Due to the first of all, informants make meaning in their world and. Secondly, the researchers try to decode the meaning to understand informants (Smith \& Pietkiewicz, 2014). IPA hermeneutics is used to encourage researchers to take empathetic attitudes and imagine what it's like to be a participant. It is critical, what seems to be the case and investigate meaning in ways that participants might not want. Imagining oneself as a participant aims to produce an understanding of rich experiences about the phenomenon being investigated and remain close to the participant's common sense. The critical attitude requires researchers to put aside what they have previously received to develop a meaningful narrative.

\section{Materials and Methods}

\section{Semi-Structured Interview, Best IPA Data Collection Method}

IPA researchers want to analyze in detail how participants understand and interpret the things that happen to them. Therefore, a flexible data collection instrument is needed. It is possible to obtain data suitable for IPA analysis in a number of ways namely personal accounts and diaries. The best way to collect data for IPA study is through semi-structured interviews. The interview form allows researchers and participants to engage in dialogue. Wherein, the initial questions are modified based on participant responses and researchers can investigate interesting and important areas that emerged during the interview. Semistructured interviews facilitate relationships and empathy, allow higher coverage flexibility and allow interviews to enter.

Juliantini, N. K. D., Sudana, I. P., Suprasto, H. B., \& Putri, I. G. A. M. A. D. (2019). Gender and work-life balance: A phenomenological study on Balinese female auditor. International Journal of Social Sciences and Humanities, 3(2), 224-237. https://doi.org/10.29332/ijssh.v3n2.318 
The strategy often is used to encourage the person to talk about the topic, little encouragement from the interviewer as possible. A good interview technique, therefore, often involves the gentle encouragement of the interviewer rather than being too explicit. Smith \& Osborn (2008), gave several tips in interviews in collecting research data using IPA method. The questions must be neutral, uncharged, or lead; avoid jargon or technical expertise assumptions; use open, not closed questions to make informants open their thoughts and feelings.

Interviews are important for recording. Write down everything the participant stated during the interview, making the interviewer only grasp the essence and lose important nuances. This also disrupts the interview running smoothly. However, in the case, the informant does not like to be recorded and may not even agree to the interview. If it is recorded, it is also important to repeat the interview to produce proper data.

\section{Analysis of IPA}

The assumption on IPA is analysts are interested in learning something about the informant's psychological world. It aims to provide evidence that participants understand the phenomenon being investigated. It is to try understanding document. Thus, the researchers move between an emic and ethical perspective. The informant's story itself can be stated to represent a piece of the informant's identity.

The analysis was conducted at aiming to try to understand the content and complexity of the meaning, an experience without measuring the experience frequency. The analysis process is related to interpretive relations with transcripts. Wherein, the meaning process is not available transparently. A transcript is obtained through ongoing involvement with the text and interpretation process. A study can be in the form of a single case design or involve a number of participants.

\section{Results and Discussions}

\subsection{Informant}

The researcher presents four themes that appear in interviews. They have been conducted with three informants. The theme built was related to their life, their role as an auditor, and a housewife wrapped in Hinduism and Balinese customs. The researcher knows the informant through a friend. They agree to participate the researcher sends a research proposal via email to provide an understanding of the research. The summary results did not use their true identity to maintain informant confidentiality. It was agreed between the researchers and the informants. There were personal things, they conveyed in the interview.

The researcher personally did not know the informant. The interview was carried out in a relaxed situation and took lunchtime on weekdays. It was not easy to ask for an interview. Considering the informants status as women with multiple roles, they have divided their time well to ensure that the functions of the auditor and housewives proper running. They are reluctant to give a portion of their time with their families to conduct interviews. They are more comfortable taking lunchtime on workdays. The auditor's schedule is not too tight. At the beginning of the meeting, the researcher explained the research conducted accompanied by self-introduction. Next, the researchers asked the informants to introduce themselves.

The first informant is Riana who has two children at school age. She does not live with her husband and parents. Riana's husband is a manager-level employee at a national company who in his work follows the pattern of employee transfers (mutations) throughout Indonesia. Every day, in carrying out her function as a mother, Riana is assisted by a household assistant who has faithfully accompanied her for almost nine years. The second informant is Nindi who has a child at preschool age. Nindi lives with her husband, children, inlaws, and family-in-law. Nindi's husband works for the local government. Every day, in carrying out her role as a mother, Nindi is assisted by her husband and parents-in-law. The third informant is Lili who has two children at school age and is a teenager. Lili lives only with her children because her husband works abroad. Nowadays, Lili is not helped by anyone in carrying out her function as a mother. In his career life as a government auditor, all informants followed the pattern of mutation throughout Indonesia. 
3.2 Representing Work-life Balance

Informants are not willing to spend time with family for research interviews. It indicates the family is the core in achieving work-life balance. This meaning was not obtained by the informants instantly, they have experienced when choosing work over the family was disappointing. Riana stated that.

"Saya berusaha memberi batas yang jelas antara pekerjaan dan keluarga, dan saya harus bisa menghentikan ketika waktu kerja hendak mengambil waktu keluarga. Pekerjaan tidak akan pernah ada habisnya, waktu saya selama 8 jam sudah habiskan di kantor, sisanya saya dedikasikan kepada keluarga dan untuk beristirahat. Pertama kalinya saya kecewa pada instansi adalah ketika saya terpaksa mengambil tanggung jawab sebagai ketua tim, saat itu saya sampai harus kehilangan anak dalam kandungan saya. Saya tidak menyalahkan siapa-siapa, meskipun atasan saya merasa bersalah, saya tidak menyimpan amarah pada beliau. Kejadian itu menjadi titik balik dalam hidup saya."

"I try to give a clear line between work and family. I have to be able to stop when working time is about to take family time. The work will never end, my time for eight hours has been spent in the office, I dedicate the rest to my family and to rest. The first time I was disappointed with the agency was when I was forced to take responsibility as a team leader, at that time, I had to lose my child in my womb. I don't blame anyone, even though, my boss feels guilty, I don't keep anger at him. It was a turning point in my life."

Parkes \& Langford (2008), stated that maintaining the health and safety of employees, and improving the reward system and performance appraisal is very important to create work-life balance. Companies can facilitate the employee's needs can increase job satisfaction. It supports the achievement of work-life balance. Furthermore, Lili who used to be independent since she was a child because she had to live far from her parents, stated that living life like flowing water, and not seeing it as a burden is the key in creating work-life balance. Lili stated that.

"Saya menjalani kehidupan ini dengan selalu berbahagia dalam setiap langkah, saya tidak memandang kehidupan sebagai beban, saya berusaha menerima dengan bijak apapun kondisi yang hadapi, dengan perbaikan disana sini saya rasa saya selalu belajar dalam hidup ini."

"I live in this life with happiness in every step, I do not see life as a burden, I try to accept wisely whatever conditions I face, with improvements here and I think there, I always learn in this life." (P3-1)

All informants tried not to pursue a career in achieving goal work-life balance. They were reluctant to take higher positions for fear of reducing their time with family. The children still needed their full attention. Riana stated that.

"Saya sudah pernah menjalani pendidikan sebagai ketua tim, seharusnya saya bisa saja mengambil jabatan sebagai pemeriksa madya di instansi saya, namun semakin tinggi jabatannya semakin besar tanggung jawabnya. Selain itu waktu mutasi juga jadi semakin cepat dan sudah tidak mengikuti pola mutasi yang ada."

"I have been educated as a team leader. I should have been able to take a position as an intermediate examiner in my agency. However, the higher the position the higher responsibility. Besides that, the mutation time also becomes faster and doesn't follow the existing mutation pattern. "

Next Nindi stated that.

"Semakin tinggi jabatannya, kompensasinya juga semakin tinggi sih, bahkan kalau kita dimutasipun ada dana pindahnya, yang jumlahnya juga besar, tapi uang pindah itu pasti habis untuk mengurus pindah sekolah anak. Taraf kesuksesan dalam karir itu menurut saya sangat relatif dan subjektif, bagi saya sendiri saya sudah sukses karena saya sudah mandiri dalam kehidupan."

"The higher position, the higher compensation, anyway, even if we are transferred, there is a transfer fund, the amount is also large. However, the transfer money must be used up to take care of the transfer of

Juliantini, N. K. D., Sudana, I. P., Suprasto, H. B., \& Putri, I. G. A. M. A. D. (2019). Gender and work-life balance: A phenomenological study on Balinese female auditor. International Journal of Social Sciences and Humanities, 3(2), 224-237. https://doi.org/10.29332/ijssh.v3n2.318 
children's schools. The success level career, in my opinion, is very relative and subjective, for myself, I have been successful because I am already independent in life."

\subsection{Finding Motivation Triggers}

The profession as a government auditor for all informants is a tough profession. All respondents have been in the profession of government auditors for more than ten years. They are very familiar with the techniques used in conducting audit activities. They have even had a second-degree education. Their careers are appropriate to occupy a higher position than now. The harsh work environment actually lies not in the audit processes and procedures they carry out. Due to the mutation patterns that must be faced by the informants, routinely every five years. They have to face the possibility of moving which is still a mystery to them.

Staying on the profession as a government auditor requires enormous motivation. Codori (1988), stated that the key to motivating auditors is with effective communication. It is important to motivate auditors is salary, perception of fair treatment in the organization, access to training, and work environment. They found their greatest motivation for surviving the government auditor profession was family. Nindi stated that.

"Dukungan terbesar dalam menjalani semua ini adalah suami saya, suami saya berkomitmen akan mengikuti saya kemanapun saya ditugaskan, dan kami tidak akan pernah berpisah, dia akan selalu menjaga keutuhan kami, dia, saya dan anak kami. Saya sangat beryukur pekerjaan suami saya memungkinkan suami saya untuk ikut kemanapun saya ditugaskan."

"The biggest support in undergoing all this is my husband. My husband is committed to following me wherever I am assigned, and we will never be separated. He will always maintain our wholeness, he, me and our children. I am very grateful that my husband's work allows my husband to join wherever I am assigned."

Fishbein \& Ajzen (2011), stated that someone will do an action if s/he views the act positively and if s/he believes others want her/him to do it. Practice or behavior according to Theory of Reasoned Action is influenced by intention. The intention is influenced by attitudes and subjective norms. The attitude itself is influenced by the belief in the opinions of others and the motivation to obey these opinions. Riana stated that.

"Ibu saya adalah motivasi terbesar saya, saya tetap bertahan karena Ibu saya berpesan agar apapun yang terjadi saya tidak pernah berhenti bekerja. Orang tua saya bersedia membantu membesarkan anak-anak saya, apabila saya ditugaskan ditempat yang berat. Kita tidak bisa meramalkan masa depan, saya tidak tau apakah suami saya akan selalu dapat menyokong secara ekonomi. Saya merasa lebih aman dalam menghadapi masa depan karena saya masih memiliki karir saya."

"My mother is my biggest motivation, I persevere because my mother told me that, no matter what happens I never stop working. My parents are willing to help raise my children if I am assigned to a tough place. We cannot predict the future, I don't know whether my husband will always be able to support economically. I feel safer in facing the future because I still have my career."

Furthermore, Lili stated that.

"Anak adalah motivasi terbesar saya untuk selalu berbahagia dalam menjalani kehidupan. Saya ingin memberikan yang terbaik kepada anak-anak saya. Suami dan saya bekerja keras demi mewujudkan impian anak-anak. Anak kami ingin melanjutkan studi di luar negeri."

"Children are my biggest motivation to always be happy in life. I want to give the best to my children. My husband and I work hard to realize the children's dream. Our child wants to continue their studies abroad."

\subsection{Challenges in Achieving Work-life Balance}

Achieving work-life balance for informants is an endless struggle, a learning process that is rolling with improvements here and there. Informants feel they must always be strong in life. With so much support from the family, the informants are always and stronger in every step of the way. Their achievements currently they 
consider being a blessing from God. All informants felt lucky and repeatedly expressed their gratitude to God in our interviews. They have achievements obtained are not something that is instant. All informants draw on experiences they have encountered with joy. They face challenges up to now give a deep impression and become a sign of their success in achieving life balance.

Challenges in achieving work-life balance arise in various life aspects, they are in a career, family, and social aspects in the form of customs. The biggest career challenge is the pattern of mutations faced by informants. They must be prepared to face the transfer of work locations. Riana stated the difficulty of planning for the future due to this mutation pattern. Riana stated that.

\begin{abstract}
"Saya telah menikah dengan suami selama tiga belas tahun. Dalam tiga belas tahun ini, waktu bertatap muka bagi kami mungkin tidak sampai melebihi satu tahun. Suami saya tidak pernah memaksa saya untuk bekerja, suami menyerahkannya kepada saya, suami selalu mendengarkan keluhan saya. Suami saya mendukung saya kapanpun saya hendak berhenti bekerja. Karena pindahnya suami selalu diberikan manfaat perumahan oleh perusahaan, dan kompensasi yang diberikan juga lebih dari cukup. Pola mutasi membuat saya merasa saya sulit merencanakan masa depan, saya jadi takut untuk membeli properti untuk rumah tinggal tetap."
\end{abstract}

"I have been married to my husband for thirteen years. In these thirteen years, our face-to-face time may not exceed one year. My husband never forced me to work. My husband gave it to me, my husband always listened to my complaints. My husband supports me whenever I want to stop working. Due to the mutation of the husband is always given housing benefits by the company, and the compensation provided is also more than enough. Mutation patterns make it difficult for me to plan for the future. Therefore, I am afraid to buy property for permanent housing."

The research on work-life balance in the accounting field has led to alternative work arrangements in response to reducing work-life conflicts and employee fatigue. Buchheit et al., (2016), stated that the benefits of alternative work arrangements are increasingly felt in professional accountants who experience increasingly high conflict level. The alternative work arrangements can be in the form of flexible work schedules, work from home, and part-time work (Mas \& Pallais, 2017; Dewi \& Dwiyanti, 2018).

All informants stated that on conducting audit activities, the challenge lies with the party being audited. They must be smart in presenting the findings and recommendations of audit results. Not infrequently, the informant must withdraw from the meeting because of pressure and intimidation from a third party who is suspected to be part of the party being audited. Lili stated that.

"Saya pernah menerima pesan singkat dari pihak yang tidak dikenal, ini seperti surat kaleng sih menurut saya."

"I once received a short message from an unknown party, this is like an anonymous letter, in my opinion."

According to Nindi:

"Pengalaman yang dialami oleh rekan sejawat, cukup memberikan pelajaran bagi saya. Ada rekan sejawat yang dipukuli oleh preman karena tidak terima akan temuan auditnya. Untuk menghindari terjadinya hal-hal yang tidak diinginkan saya memilih untuk memberikan skala prioritas pada temuan saya."

"The experience felt any colleagues is enough to teach me a lesson. Some colleagues were beaten by thugs because they did not accept the audit findings. To avoid undesirable things, I chose to give priority to my findings."

Regarding accountability and reactions Barnett \& Hyde (2001) and Ghafran \& O'Sullivan (2013), stated that the party being audited used a different strategy when held accountable. The auditor's ability to deliver the audit results greatly influences the response of the auditee. The auditor must also be proficient in linking findings with regulations that underlie the existence of corrections. Therefore, it is to minimize negative reactions from the party being audited.

Nindi gets her biggest challenge from her social life which is customs. Nindi's husband comes from Bali area. It still adheres to customs. Customs are indeed different in each region, there are some areas that are still

Juliantini, N. K. D., Sudana, I. P., Suprasto, H. B., \& Putri, I. G. A. M. A. D. (2019). Gender and work-life balance: A phenomenological study on Balinese female auditor. International Journal of Social Sciences and Humanities, 3(2), 224-237. https://doi.org/10.29332/ijssh.v3n2.318 
very strong there are customs, and conversely, there are some areas where customs are not so binding. The more flexible customs make it easy for Balinese Hindus who are not in their home regions. They gained freedom on "ayahan banjar" event. The offerings field those with more flexible customs have become accustomed to buying offerings for prayers. Nindi stated that.

"Saya tidak mengerti perihal pembuatan banten, dalam kegiatan ngayah saat ada odalan, saya jadi tidak bisa membantu mertua. Saya beruntung karena mertua saya pengertian, ibu mertua juga masih sehat. Mertua saya tidak pernah memaksa saya untuk belajar membuat banten, karena memahami profesi saya yang tidak akan menetap lama di Bali. Saya juga beruntung karena kakak ipar saya adalah orang yang mengerti banten, jadi sudah ada kakak ipar yang mengambil alih fungsi adat istiadat keluarga suami."

"I do not understand about making offerings, ngayah activities when there is a festival day (odalan), I cannot help my parents-in-law. I was lucky because my mother-in-law was understanding, mother-in-law was also still healthy. My father-in-law never forced me to learn to make offerings, he understands to my profession would not last long in Bali. I am also fortunate because my brother-in-law is someone who understands offerings, so, there is already a brother-in-law who has taken over the functions of the husband's family customs."

Social changes are currently affecting Balinese as globalization consequence has made procurement offerings accessible through the market as a commodity (Atmadja \& Ariyani, 2016; Sanjaya Adi Putra \& Dwirandra, 2019). Nowadays, there are many Balinese who choose to buy offerings (banten) rather than make it themselves. This is not only to feel more practical but also happens due to many sales centers offer. The increasing number of sellers offer it, causing it to be easier to be obtained.

Religious belief is generally passed down by birth. Religious dogma interpretation by individuals sometimes leads to mistakes. They are often used as a means towards the individual or group goals (Aldashev \& Platteau, 2014). Riana stated that.

"Saya tidak mengerti banten, selama ini saya membeli banten di pasar dekat rumah saya. Suami berasal dari daerah yang adat istiadatnya masih sangat kuat, dan saat ini saya ada di Bali jadi saya sering kali pulang ke kampung halaman ketika ada odalan. Tapi saya sangat beruntung karena di kampung halaman saya ada sodara sepupu yang membantu saya dalam membuat banten. Saya hanya memberikan bantuan dalam pendanaan saja. Sanggah besar yang di kampung halaman juga dibantu penjagaannya oleh sodara sepupu. Semua saudara kandung suami saya merantau, tidak ada yang tinggal di Bali. Jadi saat ini hanya saya saja yang tinggal di Bali. Tantangan lain dalam adat istiadat, adalah saya yang sampai saat ini tidak mampu memahami sudut pandang saudara Hindu Bali. Saya menikah di sebuah Pura di Jawa, dihadiri oleh keluarga saya dan keluarga suami. Tapi saya diminta mengulangi prosesi pernikahan di Bali, dengan alasan bahwa belum disaksikan oleh desa adat di Bali. Pada akhirnya saya terpaksa mengulangi prosesi pernikahan di kampung halaman suami, dengan biaya yang sangat besar. Saya dan suami sangat kecewa pada saat itu."

"I do not understand the offer, so far I have bought banten in a market near my home. My husband comes from an area where customs are still very strong, and currently, I am in Bali so I often return to my hometown when there is an odalan. But I was very lucky because in my hometown there was a cousin. My cousin who helped me in making offerings. I only provide assistance in funding. Large protests at home are also helped by their cousins. All my husband's siblings wander, none of them live in Bali. So, I now just live in Bali. Another challenge in customs is not been able to understand the viewpoint of my Balinese Hindu brothers. I was married in a temple in Java, attended by my family and husband's family. But, I was asked to repeat the wedding procession in Bali, arguing that it had not been witnessed a traditional village in Bali. In the end, I was forced to repeat the marriage procession in my husband's hometown, at a very large cost. My husband and I were very disappointed at the time."

\subsection{Strategy on Achieving Work-life Balance}

Regarding the support and motivation of the family, the informant developed various strategies to achieve work-life balance. Every experience in a role both work or family will improve one's life quality (Kumar \& Janakiram, 2017). According to Gerson (2016), based on expansionist theory, the dual role performed on working mothers provides many benefits to both family members. The family members become better prepared to face unexpected challenges. Hyde (2015), stated that the dual role performed by a person is 
beneficial for physical, mental, and social health. It is faced various challenges on achieving work-life balance. The informant developed various strategies that could help realize work-life balance. Lili stated that.

"Sejak kecil anak saya sudah mengajarkan cara memasak kepada anak-anak saya. Saya menyediakan bahan makanan yang mudah dimasak oleh anak-anak saya. Saya juga mengajarkan mereka kegiatan domestik lain seperti mencuci baju dan mencuci piring. Saya mendidik mereka untuk bertanggung jawab sejak dini. Dalam kegiatan belajar, saya mendidik anak-anak agar setia pada proses. Hal ini menyebabkan anak saya selalu merasa bangga atas semua capaian yang diperolehnya, karena setiap capaian mereka adalah hasil dari kerja keras mereka sendiri. Saya juga mengajarkan mereka untuk mengejar mimpi dan cita-cita mereka. Saya selalu mendukung cita-cita mereka."

"Since childhood, my child has taught my children how to cook. I provide food that is easily cooked by my children. I also taught them other domestic activities such as washing clothes and washing dishes. I educate them to take responsibility early on. In learning activities, I educate children to be faithful to the process. This causes my child to always feel proud of all the achievements he obtained because each of their achievements is the result of their own hard work. I also teach them to pursue their dreams and ideals. I always support their ideals."

The women are figures who have tenderness and strength. The great power possessed woman will give birth to a great responsibility. The dual role is carried out. It is the harmonization of accountability values (Komalasari et al., 2019). No family member can help, the informant builds trust and delegates her role as a mother. Of course, all decisions taken the informant aim to facilitate the dual role she does. Riana stated that.

"Saya mencari kontrak rumah yang sangat dekat dengan tempat kerja saya dan sekolah anak-anak, meskipun harganya sangat fantastis. Saya juga membagi waktu sebaik mungkin agar saya bisa mengantar dan menjemput anak sekolah. Untuk kegiatan domestik rumah tangga, saya memberikan kepercayaan kepada asisten rumah tangga saya. Disaat saya benar-benar tidak bisa mengantar dan menjemput mereka sekolah, saya mendelegasikannya kepada asisten rumah tangga saya. Asisten rumah tangga saya akan mengantarkan anak sekolah dengan berjalan kaki. Saya menyadari bahwa saya adalah ibu dengan peran ganda, maka saya tidak bisa mengajarkan anak-anak saya dirumah. Untuk meningkatkan kemampuan dan edukasi mereka, anak-anak saya mengikuti les di beberapa tempat. Ketika saya tidak bisa mengantarkan mereka ketempat les, saya memberikan kepercayaan kepada istri dari tenaga keamanan di kantor saya. Kebetulan istrinya tidak bekerja, jadi tugasnya adalah mengantar dan menjemput anak saya les."

"I am looking for a house contract. It is very close to my workplace and children's school, even though, the price is fantastic. I also divide my time as best as I can. So that I can deliver and pick up school children. For domestic household activities, I give confidence to my household assistant. When I really can't deliver and pick them up at school, I delegate it to my household assistant. My household assistant will take the school children on foot. I realized that I was a mother with multiple roles, so, I could not teach my children at home. To improve their abilities and education, my children attend tutoring in several places. When I was not able to take them to the tutoring place, I gave trust to the security personnel in my office. It so happened that his wife did not work. Therefore, his job was to take and pick up my son to take lessons."

The strategies developed the informants vary greatly according to each informant conditions. Work-life balance also has a different meaning for each person (Rehman \& Roomi, 2012). The time commitments for the family are the most important core values. Women who have supported their husbands believe that they have achieved work-life balance. Nindi who lives with family developed a different strategy from other informants. According to Nindi.

"Saya memang sangat beruntung memperoleh suami yang pengertian, suami saya menyadari profesi, sehingga suami saya dengan senang hati mengurus kebutuhan buah hati kami dalam sekolah. Suami sayalah yang mengantar jemput anak saya sekolah. Saat anak saya tidak sekolah, anak saya dijaga oleh mertua saya, mertua saya adalah seorang nenek yang baik, saya beruntung sekali beliau masih kuat. Selain itu, karena saya tinggal dalam lingkungan yang sama dengan kakak ipar, maka anak-anak kami juga saling menjaga. Sesekali, ketika profesi saya sebagai auditor menuntut saya untuk tidak bisa pulang, karena lokasi audit yang jauh dari rumah saya, saya memboyong suami dan anak saya untuk ikut serta

Juliantini, N. K. D., Sudana, I. P., Suprasto, H. B., \& Putri, I. G. A. M. A. D. (2019). Gender and work-life balance: A phenomenological study on Balinese female auditor. International Journal of Social Sciences and Humanities, 3(2), 224-237. https://doi.org/10.29332/ijssh.v3n2.318 
kesana. Sebagai auditor, ketika melakukan kegiatan audit, saya memang diberikan fasilitas menginap dari kantor, apabila lokasi auditnya jauh dari kota Denpasar."

\begin{abstract}
"I am indeed very fortunate to have an understanding husband, my husband is aware of the profession. Thus, my husband is happy to take care of our baby's needs in school. It was my husband who drove my child to school. When my child is not in school, my child is looked after by my in-laws. My in-laws are good grandmothers, I am very fortunate that she is still strong. In addition, because I live in the same environment as my sister-in-law, our children also take care of each other. Occasionally, when my profession as an auditor demands that I am not able to go home because the audit location is far from my home, I bring my husband and child along to participate there. As an auditor, when I conduct audits, I am indeed given the facility of staying overnight from the office, if the audit location is far from Denpasar city."
\end{abstract}

\title{
4. Conclusion
}

The interviews results show the concept of work-life balance for each informant is very varied. The variations occurred due to each informant is in different conditions and situations. Some things cause different views in representing work-life balance in life are workplace conditions (colleagues and superiors). The rules are on profession (severe mutation patterns), spouse (husband), close family, children, and differences in Balinese Hindu customs. All informants almost have the concept of achieving work-life balance is always happy in life. Informants achieve work-life balance on living a happy and always grateful life.

The challenge of achieving work-life balance arise in various aspects of life, both in career, family, and social aspects in the form of customs. The challenge on family experienced by the informants is childcare. Informants who are at the age of pre-schoolers and school children still need time and attention from parents. The biggest career challenge is the pattern of mutations faced by informants. They must be prepared to face the transfer of work locations. Mutation patterns make it difficult for informants to plan for the future. The development of alternative work arrangements is felt to be a solution to reduce work-life conflict and female auditor fatigue.

The strategies that were developed by informants in achieving work-life balance vary greatly according to each informant conditions. It was related to family conflicts experienced by informants. They sought the household assistants services in delegating child supervision while they worked. Other informants feel very fortunate due to they can be assisted their husband and parents-in-law in supervising their children. Regarding work conflicts, the informants chose to give priority to the findings. They also honed their ability to convey their findings. Therefore, the conflicts on the auditee did not occur. Informants must also be disciplined in dividing time between work and family, remembering that office work will never run out.

\section{Acknowledgments}

The authors would like to acknowledge the editor of IJSSH for their valuable time, support, and advice. 
References

Aditya, A. G. D., \& Kusuma, M. G. W. (2019). The effect of tri hita karana culture in relationship between work stress and internal auditor performance. International Research Journal of Management, IT and Social Sciences, 6(2), 72-78. https://doi.org/10.21744/irjmis.v6n2.610

Aldashev, G., \& Platteau, J. P. (2014). Religion, culture, and development. In Handbook of the Economics of Art and Culture(Vol. 2, pp. 587-631). Elsevier. https://doi.org/10.1016/B978-0-444-53776-8.00021-0

Atmadja, A. T., Ariyani, L. P. S., \& Atmadja, N. B. (2016). Women as Canang Sari Street Vendors in Bali. Komunitas: International Journal of Indonesian Society and Culture, 8(1), 85-93.

Barnett, R. C., \& Hyde, J. S. (2001). Women, men, work, and family: An expansionist theory. American psychologist, 56(10), 781.

Breesch, D., \& Branson, J. (2009). The effects of auditor gender on audit quality. IUP Journal of Accounting Research \& Audit Practices, 8.

Buchheit, S., Dalton, D. W., Harp, N. L., \& Hollingsworth, C. W. (2015). A contemporary analysis of accounting professionals' work-life balance. Accounting Horizons, 30(1), 41-62. https://doi.org/10.2308/acch-10672

Codori, C. A. (1988). Positively motivating auditors and Managers. Managerial Auditing Journal, 3(2), 21-23.

Cresswell, J. W. (2003). Research design: qualitative and mixed-method approaches.

Creswell, J. W. (2007). Qualitative inquiry and research method: Choosing among five approaches.

Darmayanti, I. A. M. (2014). Seksualitas Perempuan Bali Dalam Hegemoni Kasta: Kajian Kritik Sastra Feminis Pada Dua Novel Karangan Oka Rusmini. Jurnal Ilmu Sosial dan Humaniora, 3(2).

Dewi, I. G. A. A. P., \& Dewi, P. P. (2018). Big Five Personality, Ethical Sensitivity, and Performance of Auditors. International Research Journal of Management, IT and Social Sciences, 5(2), 195-209.

Dewi, P. P., \& Dwiyanti, K. T. (2018). Professional commitment, self-efficacy and ethical decision auditor. International Research Journal of Management, IT and Social Sciences, 5(6), 93-104. https://doi.org/10.21744/irjmis.v5n6.379

Dewi, R. S., \& Holiawati. (2016). Pengaruh Work Life Balance Dan Locus Of Control Terhadap Kualitas Audit Dengan Gender Sebagai Variabel Pemoderasi.

Fishbein, M., \& Ajzen, I. (2011). Predicting and changing behavior: The reasoned action approach. Psychology press.

Gerson, K. (2016). Expansionist Theory Expanded: Integrating Sociological and Psychological Perspectives on Gender, Work, and Family Change. In Gender and Couple Relationships (pp. 111-119). Springer, Cham.

Ghafran, C., \& O'Sullivan, N. (2013). The governance role of audit committees: reviewing a decade of evidence. International Journal of Management Reviews, 15(4), 381-407. https://doi.org/10.1111/j.14682370.2012.00347.x

Hardies, K., Breesch, D., \& Branson, J. (2010). Are female auditors still women? Analyzing the sex differences affecting audit quality. Analyzing the Sex Differences Affecting Audit Quality (January 14, 2010).

Hausmann, R., Tyson, L. D., \& Zahidi, S. (2017). The Global Gender Gap Report 2017. World Economic Forum.

Hyde, J. S. (2016). Women, men, work, and family: Expansionist theory updated. In Gender and couple relationships (pp. 93-109). Springer, Cham.

Ittonen, K., \& Peni, E. (2012). Auditor's gender and audit fees. International Journal of Auditing, 16(1), 1-18. https://doi.org/10.1111/j.1099-1123.2011.00438.x

Komalasari, Y., Wirajaya, I. G. A., \& Sari, M. M. R. Akuntabilitas Akuntan Perempuan-Karir Bali: Sebuah Studi Fenomenologi. Jurnal Ilmiah Akuntansi dan Bisnis, 70-85. https://doi.org/10.24843/JIAB.2019.v14.i01.p07

Kumer, G. V., \& Janakiram, B. (2017). Theories of Work Life Balance-a Conceptual Review. International Research Journal of Management and Commerce, 4(9), 184-192.

Mas, A., \& Pallais, A. (2017). Valuing alternative work arrangements. American Economic Review, 107(12), 3722-59. https://doi.org/10.1257/aer.20161500

Mayaswari, W. H., \& Yasa, I. G. W. M. Peran ganda pedagang perempuan di pasar seni mertha nadi legian, bali. Populasi, 23(2), 71-84. https://doi.org/10.22146/jp.15696

Niskanen, J., Karjalainen, J., Niskanen, M., \& Karjalainen, J. (2011). Auditor gender and corporate earnings management behavior in private Finnish firms. Managerial Auditing Journal, 26(9), 778-793. https://doi.org/10.1108/02686901111171448

Juliantini, N. K. D., Sudana, I. P., Suprasto, H. B., \& Putri, I. G. A. M. A. D. (2019). Gender and work-life balance: A phenomenological study on Balinese female auditor. International Journal of Social Sciences and Humanities, 3(2), 224-237. https://doi.org/10.29332/ijssh.v3n2.318 
Parkes, L. P., \& Langford, P. H. (2008). Work-life bal ance or work-life alignment? A test of the importance of work-life balance for employee engagement and intention to stay in organisations. Journal of Management \& Organization, 14(3), 267-284. https://doi.org/10.1017/S1833367200003278

Pietkiewicz, I., \& Smith, J. A. (2014). A practical guide to using interpretative phenomenological analysis in qualitative research psychology. Psychological journal, 20(1), 7-14.

Rehman, S., \& Azam Roomi, M. (2012). Gender and work-life balance: a phenomenological study of women entrepreneurs in Pakistan. Journal of small business and enterprise development, 19(2), 209-228. https://doi.org/10.1108/14626001211223865

Sanjaya Adi Putra, G., \& Dwirandra, A. A. N. B. (2019). The effect of auditor experience, type of personality and fraud auditing training on auditors ability in fraud detecting with professional skepticism as a mediation variable. International Research Journal of Management, IT and Social Sciences,6(2), 31-43. https://doi.org/10.21744/irjmis.v6n2.604

Smith, J. (2008). A., \& Osborn, M.(2003). Interpretative phenomenological analysis. Qualitative psychology: A practical guide to research methods, 53-80.

Smith, J. C. (1990). Cognitive-behavioral relaxation training: A new system of strategies for treatment and assessment. Springer Publishing Co.

Smith, K. T., Smith, M., \& Brower, T. R. (2010). An examination of work-life balance perspectives of accountants. International Journal of Critical Accounting, Forthcoming.

Suarmika, P. E., \& Utama, E. G. (2018). Gender differences (purusa pradana) and metacognitive skills in bali. JPDI (Jurnal Pendidikan Dasar Indonesia), 3(1), 14-17. http://dx.doi.org/10.26737/jpdi.v3i1.524 


\section{Biography of Authors}

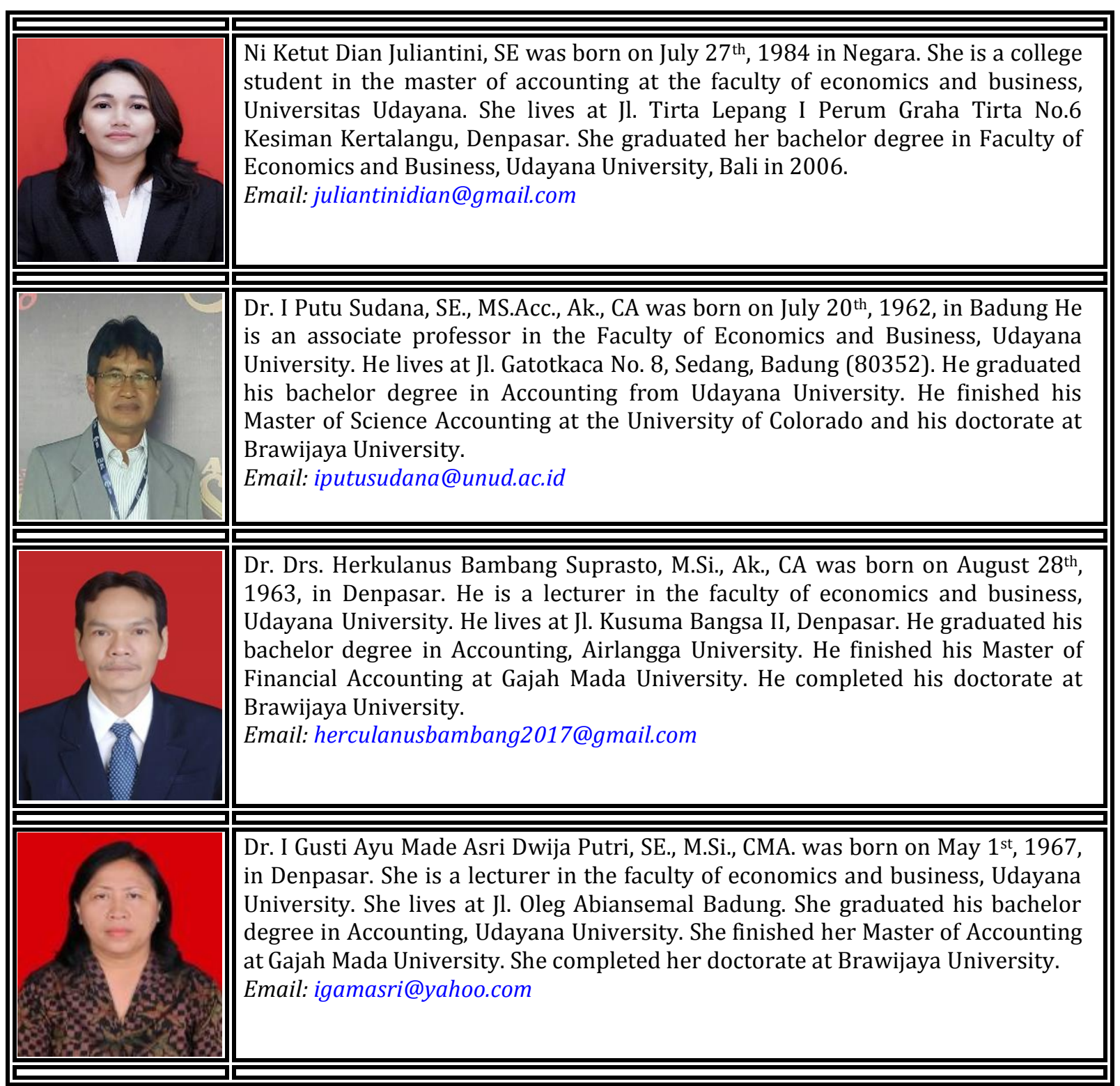

Juliantini, N. K. D., Sudana, I. P., Suprasto, H. B., \& Putri, I. G. A. M. A. D. (2019). Gender and work-life balance: A phenomenological study on Balinese female auditor. International Journal of Social Sciences and Humanities, 3(2), 224-237. https://doi.org/10.29332/ijssh.v3n2.318 